\title{
Rate of synthesis of coagulation factors II, VII, IX, and $X$ during substitution therapy with P.P.S.B.
}

Citation for published version (APA):

Loeliger, E. A., Hensen, A., Mattern, M. J., \& Hemker, H. C. (1965). Rate of synthesis of coagulation factors II, VII, IX, and X during substitution therapy with P.P.S.B. In L. P. Holländer (Ed.), Proceedings of the Tenth Congress of the International Society of Blood Transfusion, Stockholm, September 1964: Part 5: Therapy of Acute Blood Loss and of Coagulation Disorders (1 ed., Vol. 5, pp. 1346-1347). S. Karger AG. International Society of Blood Transfusion Vol. 23 https://doi.org/10.1159/000384472

Document status and date:

Published: 01/01/1965

DOI:

10.1159/000384472

Document Version:

Publisher's PDF, also known as Version of record

\section{Please check the document version of this publication:}

- A submitted manuscript is the version of the article upon submission and before peer-review. There can be important differences between the submitted version and the official published version of record.

People interested in the research are advised to contact the author for the final version of the publication, or visit the DOI to the publisher's website.

- The final author version and the galley proof are versions of the publication after peer review.

- The final published version features the final layout of the paper including the volume, issue and page numbers.

Link to publication

\footnotetext{
General rights rights.

- You may freely distribute the URL identifying the publication in the public portal. please follow below link for the End User Agreement:

www.umlib.nl/taverne-license

Take down policy

If you believe that this document breaches copyright please contact us at:

repository@maastrichtuniversity.nl

providing details and we will investigate your claim.
}

Copyright and moral rights for the publications made accessible in the public portal are retained by the authors and/or other copyright owners and it is a condition of accessing publications that users recognise and abide by the legal requirements associated with these

- Users may download and print one copy of any publication from the public portal for the purpose of private study or research.

- You may not further distribute the material or use it for any profit-making activity or commercial gain

If the publication is distributed under the terms of Article $25 \mathrm{fa}$ of the Dutch Copyright Act, indicated by the "Taverne" license above, 


\title{
Rate of Synthesis of Coagulation Factors II, VII, IX, and X During Substitution Therapy with P.P.S.B.
}

\author{
E. A.Loeliger; A. Hensen; M. J. Mattern and H.C. Hemker (Leyden, The Netherlands)
}

P.P.S.B., which I had been told by Dr. SouLIER is now commercially available in sufficient amounts to be used on a large scale, appeared most suitable and convenient for the treatment of haemophilia B [I, 2]. Shortages of factors II, VII, and $\mathrm{X}$, with the exception of acquired factor II-deficiency in lupus erythematosus and acquired factor $\mathrm{X}$-deficiency in amyloidosis, should also respond well to P.P.S.B. Plasma levels of coagulation factors to be expected from the amount of P.P.S.B. transfused can be calculated by means of formulas used earlier [ $\mathrm{I}$ ]. It is evident that the levels obtained in a patient are proportional to the amount and to the biological $t \frac{1}{2}$ of the coagulation factors transfused. Once equilibrium between infusion rate and metabolic decay is attained in a patient displaying no production of his own, the requirement for maintenance of a $25 \%$ level would, per $\mathrm{kg} / \mathrm{hour}$, amount to the equivalent of fresh normal plasma for:

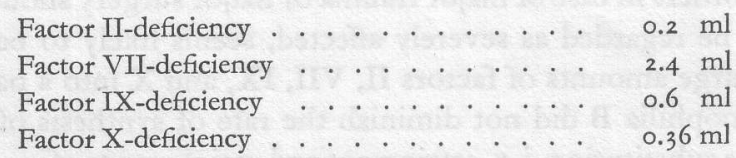

These amounts hold for normal metabolic conditions, under which the $t \frac{1}{2}$ of factors II, VII, IX, and X are $72,6,24$ and $40 \mathrm{~h}$ respectively.

What we were not sure about until recently, but nevertheless appeared all important to know from the point of view of economy of substitution therapy, was whether the rate of the patient's own synthesis of the coagulation factors under discussion was altered during substitution. If the rate of synthesis were not altered, then the level obtained during transfusion of P.P.S.B. would be the sum of the patient's own level and the level to be expected from the amount transfused. Mild cases of factors II, VII, IX, and X deficiency, that is to say cases displaying a coagulation factor activity of $5 \%-20 \%$ of the missing coagulation factor, would then require substantially less P.P.S.B. for the attainment of the safe $25 \%-30 \%$ level.

We recently had an opportunity to study a haemophilia B patient belonging to the mild variety who was operated upon under the protection of P.P.S.B. The preparation was given at a constant infusion rate and the daily amount was equivalent to about I.5 1 fresh normal plasma (factor II r.361, factor VII r.5 2 1, factor IX 0.81 , and factor X I.48 1). Pertinent coagulation factor activities in the patient's plasma were measured twice daily during the whole period of substitution. Equilibrium between the infusion rate and rate of metabolic decay of the coagulation factors 
Table I

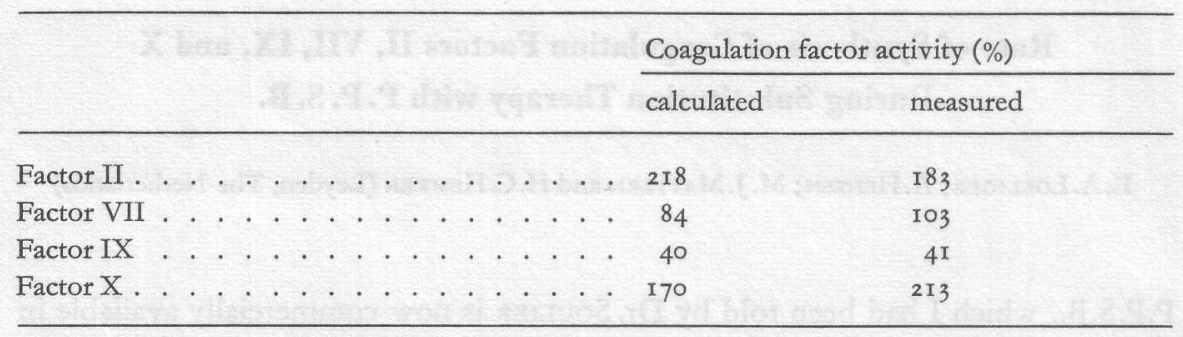

transfused was supposed to have been attained within the first four days of treatment, the plasma levels assessed between the 5 th and 9 th day being rather constant. Independence of production rate with respect to plasma levels is strongly suggested by the results obtained in this patient: as shown in table I, the plasma levels measured for factors II, VII, IX, and X appeared to be in reasonable accordance with the sum of patient's basic levels (basic levels: $96 \%, 72 \%, 16 \%$, and $95 \%$ resp.) and the level calculated from the amount transfused (calculated levels: I $22 \%$, I $2 \%, 24 \%$, and $75 \%$ resp.). All figures given in table I are average values of 8 observations.

In conclusion: Our statement, made some years ago, that patients suffering from mild coagulation disorders in case of major trauma or major surgery should with respect to substitution be regarded as severely affected, seems likely to be wrong, since transfusion of large amounts of factors II, VII, IX, and X into a patient suffering from mild haemophilia B did not diminish the rate of synthesis of these factors. Hence, adequate substitution, i.e. attainment and maintenance of a $25 \%-30 \%$ level, will be easier to obtain in mild deficiency of factors II, VII, IX, and X than in cases of severe deficiency of these coagulation factors.

\section{References}

r. Loeliger, E. A.; Hensen, A.; Mattern, M. J. and Alsbach, E.E. J.: Substitution therapy in haemophilia B. Thromb. Diath. haemorrh. 6: 39I (196r).

2. Loeliger, E. A.; Hensen, A.; Veltrkamp, J. J.; Meer, J. van Der and Hemker, H.C.: Hemophilia and hemophilioid diseases, ed. K. M. Brinkhous (Chapel Hill, University of North Carolina Press 1964).

Authors' address: Dr.E.A.Loeliger, Haematology Section of the Dept. of Internal Medicine, University Hospital, Leyden (The Netherlands) 